\title{
Profiles and Portfolios
}




\title{
Profiles and Portfolios
}

A guide for nurses and midwives

\author{
Cathy Hull and Liz Redfern
}

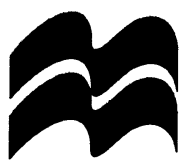

MACMILLAN 
๑) Cathy Hull, Elizabeth Redfern 1996

All rights reserved. No reproduction, copy or transmission of this publication may be made without written permission.

No paragraph of this publication may be reproduced, copied or transmitted save with written permission or in accordance with the provisions of the Copyright, Designs and Patents Act 1988, or under the terms of any licence permitting limited copying issued by the Copyright Licensing Agency, 90 Tottenham Court Road, London W1P 9HE.

Any person who does any unauthorised act in relation to this publication may be liable to criminal prosecution and civil claims for damages.

First published 1996 by

MACMILLAN PRESS LTD

Houndmills, Basingstoke, Hampshire RG21 6XS

and London

Companies and representatives

throughout the world

ISBN 978-0-333-60684-1 ISBN 978-1-349-13366-6 (eBook)

DOI 10.1007/978-1-349-13366-6

A catalogue record for this book is available from the British Library.

$\begin{array}{llllllllll}10 & 9 & 8 & 7 & 6 & 5 & 4 & 3 & 2 & 1 \\ 05 & 04 & 03 & 02 & 01 & 00 & 99 & 98 & 97 & 96\end{array}$


This book is dedicated to Vernon, Tiny and Mike, for being there and for their encouragement all along the way. 


\section{Contents}

Foreword $\quad$ xi

Acknowledgements $\quad$ xiv

Introduction $\quad \mathrm{XV}$

1. Profiles and Portfolios: The Nursing and Midwifery 1

Context

Influences on the development of profiles and portfolios 2

Uses within nursing and midwifery 9

Life-long learning $\quad 13$

An international perspective: profiles in nursing in $\quad 14$

Ontario

$\begin{array}{ll}\text { References } & 17\end{array}$

2. Getting to Grips with the Terminology 19

Continuing professional development and life-long 20

learning

Profiles and portfolios $\quad 21$

Experiential learning $\quad 24$

Reflection $\quad 26$

Credit Accumulation and Transfer Scheme (CATS) 28

APL and APEL $\quad 30$

Learning outcomes $\quad 31$

References $\quad 32$

3. Some Common Themes and Questions Shared 35

Why do I need to compile a profile? 37

Should I buy a ready-made profile? 38

How do I decide which profile to buy? 38

What can I put into it? 43

How long will it take to complete?

Who owns my profile? 44 
How do I know that the learning I am demonstrating 44 is at the appropriate level?

How much information should I include?

What should I do if I haven't written for a long time? 46

Where can I go for help?

References $\quad 48$

4. Getting Started: Creating Your Personal Profile 49

Taking stock $\quad 50$

Developing a structure $\quad 63$

Reflecting on past learning $\quad 66$

Identifying significant learning $\quad 67$

Proving what you know and can do $\quad 73$

$\begin{array}{ll}\text { Constructing your profile } & 78\end{array}$

References $\quad 84$

5. Profiles and Reflective Practice 87

Role of reflection in professional practice $\quad 88$

Reflection and learning $\quad 89$

Defining reflection and reflective practice $\quad 92$

Reflection and profiles $\quad 93$

Writing and reflecting $\quad 95$

Confidentiality $\quad 96$

Reflection - how do you do it? 98

Ideas for further work on reflection $\quad 107$

$\begin{array}{ll}\text { References } & 107\end{array}$

6. Making Your Learning Count 109

Towards a definition of accreditation $\quad 111$

Accreditation of continuing professional development 112

Credit Accumulation and Transfer Scheme (CATS) 113

National Vocational Qualifications (NVQs) 115

Claiming credit for your prior learning $\quad 117$

$\begin{array}{ll}\text { References } & 122\end{array}$

7. Helping Others to Develop a Profile: The Skills of 123 Facilitation

Learning from experience $\quad 124$

Assisting others with their profile 129 
Blocks to learning $\quad 130$

Facilitation skills $\quad 132$

Taking responsibility 134

Planning the profile $\quad 136$

Creating a good learning environment $\quad 141$

Establishing ground rules $\quad 142$

Progress chasing 143

Evaluation $\quad 143$

References $\quad 144$

$\begin{array}{ll}\text { Epilogue } & 145\end{array}$

$\begin{array}{ll}\text { Annotated Bibliography } & 157\end{array}$

$\begin{array}{ll}\text { Index } & 169\end{array}$ 


\section{Foreword}

Almost every nurse practising today will have attended, at one time or another, an award ceremony where 'the great and the good' will have taken a leaf out of Winston Churchill's book and reminded them - albeit in a different context - that 'this is not the end . . . it is the end of the beginning'. This advice has always been accompanied by the speaker stressing the need for the newly qualified practitioner to continue to learn to develop the newly acquired skills, knowledge and competences so that they can continue to provide a high standard of safe patient care.

Over the decades since I was at such a ceremony, such continuing professional development has become much easier and much more attractive. The 1970s saw the introduction and establishment of such bodies as The Joint Board of Clinical Nursing Studies (JBCNS), which offered combined clinical and education programmes in a wide range of specialist areas and of varying depth and length. By the late 1970s, the Diploma and Degree programmes were established. Such programmes as the University of London Diploma (which became a degree course in the 1980s) brought part-time advanced study to those nurses who could not reach a fixed study site such as a conventional College or University.

By the 1980s, we had integrated programmes developing, offering academic and professional credits, and the early 1990s found an even wider menu available, as the Open University and Open College joined the provider market.

The authors of the book grew up as I did, with these changes. Even more importantly, both were, and still are, actively involved in the field of published Open Learning, such as the Nursing Times programmes, the DLC (Distance Learning Centre) Projects and Health Pickup.

As the profession demanded a more flexible and accessible 
approach to continuing professional education, the National Boards and the UKCC moved to validate the opportunities and to approve the innovative programmes developing within the (then) Schools of Nursing and their associated Universities.

But many staff had qualifications which had been gained before such validations. Many more had attended the conferences, study days and workshops which were increasingly being offered, and nurses were also realising that there were things they did, other than nursing, which had merit. Examples included voluntary work and youth work.

So we saw the development of APL and APEL (Accreditation of Prior [Experiential] Learning). Again, the authors were involved in this initiative.

In order to support so much learning, so many opportunities, the profession was supported by mentors, preceptors, supervisors ...

Nurses everywhere have been inundated with advice about not only what to do and how to do it, but what to do with it when you've done it. The profession has been swamped with information on reflective practice, validation, accreditation, profiling, portfolio, APL, APEL, CATS (Credit Accumulation Transfer Scheme), CAL (Computer Assisted Learning), CEPS (Continuing Education Points scheme) and all the other educational and practice development jargon.

Confused? Join the crowd!

But two people who aren't confused are Cathy Hull and Liz Redfern. They have been amongst the leaders in Professional Development for many years and are most ably equipped to guide any nurse through the labyrinth of developing and maintaining the professional portfolio we all need. They debunk the myths, explain the terms, clarify what you need to do and - perhaps more importantly - what you do not need to do, and offer clear advice on the many ways nurses can fulfil their own continuing education needs to maintain competence and meet the requirements of PREP (PostRegistration Education for Practice). They answer every question you've thought of, as well as many you haven't. In 
short, to go back to Winston Churchill - they have indeed 'give[n] us the tools' we all need to understand the complex work of continuing professional development and the development and maintenance of our profiles and portfolios.

Dr Betty Kershaw 


\section{Acknowledgements}

We would like to acknowledge Linda Davidson for bringing us together to speak about profiles at the first Nursing Times Staff Nurse conference in Scarborough in 1992. The conference venue was the Spa and the opening session was held in what looked like an old music hall theatre with lights all around the stage. We had never met before, but we knew then that we shared the same sense of humour, passion and values about how people learn and develop.

This book would not have been possible unless we had had the opportunity to share, discuss and develop our ideas and understanding with a whole range of people along the way. The entire list would fill the book; however, we would like to thank the following for their generosity of spirit, encouragement, knowledge and time:

Susan Fey
Sue Frost
Rob Imeson
Chris James
Chris Johns
Jan Kelly

\author{
Marianne Phillips \\ Jill Rogers \\ John Storan \\ Claire Virgo \\ Susan Weil \\ Debra Witmer
}

Special thanks to Michelle Murtagh for helping with the typing, Jan Kelly for compiling the bibliography, and Debra Witmer and Maggie Wallace for their contributions and support. 


\section{Introduction}

The idea for developing this book came from our experience of speaking at nursing conferences and running workshops, and our direct involvement in helping people understand and put together profiles in a nursing and midwifery context.

Our experience led us to realise that although people quickly grasp the idea that profiling can help them to develop, they then do not know how to start. They are unsure of the practical issues, such as how to develop a profile and how they can relate it to their practice. The common questions asked in workshops are:

- Do I need to buy one?

- If I do, which one is likely to meet my needs?

- Can I do one on my own or do I need help?

- How do I express my life experience in a containable, meaningful way?

- Where do I start?

The aim of this book is to give people practical guidance on the whole continuum of profile work, from start to completion, accepting that it can be a never-ending process. The book is based on what we think people need to know to make a success of profiling and, more importantly, the issues people commonly ask for help with.

This book will give people guidance in compiling their own profiles. It is intended to act in support of the process, rather than to provide a model profile. Although we suggest activities and include an annotated bibliography of resource material that will help with the process, this is not a book that you work through, using activities to create a profile. It is intended to support the whole process of profiling.

Readers will bring their own styles and learning needs to the book and should use it in a way that works for them. We 
have written it knowing that most readers will dip in and out when they have particular learning needs, rather than read it sequentially. Each chapter has an introductory section which will help people decide if that chapter is relevant. However, the chapters do follow a logical sequence and order, which will help readers who want to read from cover to cover. It would be almost impossible to write a book that covers all the specific needs for specific educational programmes, so we have not tried to do this.

Readers will be aware that the terms profile and portfolio are used interchangeably in nursing and midwifery. This issue is addressed in several chapters and we will not repeat the arguments here. We have decided to use the term profile throughout the book unless referring to a specific product called a portfolio, because Personal Professional Profile is the term that has been chosen by the UKCC.

The book gave the opportunity for two people to combine their experience of profiles from different backgrounds for the benefits of the reader. Cathy Hull has a background in adult education, experiential processes and facilitating others in the profile process from outside nursing. Liz Redfern brings her experience of profiles and reflective practice from a professional context of nursing and midwifery practice and education. Both of us believe that as individuals we could not have written the same book, and its quality has been considerably enhanced by our collaboration. We hope you enjoy the book as much as we enjoyed working together writing it.

So what does the book contain? The following chapter-bychapter breakdown gives an overview.

\section{Chapter 1 Profiles and Portfolios: The Nursing and Midwifery Context}

This chapter charts the history and identifies the factors, such as the statutory bodies, reflective practice, market forces and higher education, that have influenced the introduction of profiles into nursing and midwifery. It also contains the outline of a profile initiative in Ontario. 


\section{Chapter 2 Getting to Grips with the Terminology}

This chapter attempts to unravel the confusion in the terminology so that everyone can understand it and use it appropriately.

\section{Chapter 3 Some Common Themes and Questions Shared}

Here we explore the ten most common questions asked about profiles.

\section{Chapter 4 Getting Started: Creating Your Personal Profile}

In this chapter you will find practical advice and activities on how to develop a framework for your profile.

\section{Chapter 5 Profiles and Reflective Practice}

This chapter attempts to demystify the concept of reflective practice and offers some practical strategies for beginners.

\section{Chapter 6 Making Your Learning Count}

This chapter will be helpful for those who are developing a profile specifically to seek accreditation within an educational programme or system.

\section{Chapter 7 Helping Others to Develop a Profile: The Skills of Facilitation}

In this chapter we look at some of the specific skills and knowledge you will need to help someone else to complete a profile. We look at how adults learn and explore the five key skills of facilitation. This chapter is written with practitioners in mind, but it might also be useful for teachers. 


\section{XVIii PROFILES AND PORTFOLIOS}

\section{Epilogue}

This concluding chapter includes the transcript of a conversation between the two authors. It is their contribution to the continuing debate on profiling.

\section{Annotated Bibliography}

We realised that it would be helpful for readers to have access to resources that will help them with the profiling process. The resource material which has been annotated in this chapter comes from several disciplines. 